\title{
Emerging perspectives on the demonstration as a signature pedagogy in design and technology education
}

\author{
Matt McLain 1
}

Accepted: 18 August 2017/Published online: 1 September 2017

(C) The Author(s) 2017. This article is an open access publication

\begin{abstract}
This paper analyses the beliefs of teachers regarding the demonstration as a signature pedagogy in design and technology, where there is a limited body of literature outlining the theory and practice. The demonstration is multifaceted, and effective teachers adopt and adapt a range of skills and values to scaffold learning, including teacher modelling and explaining. The study explores the subjective beliefs of seven practicing teachers through Q Methodology; comparing and analysing the responses of the participants' subjective beliefs and values, using 62 statements relating to teacher modelling and explaining, developed and refined with teacher educators, and representing the concourse of opinions and perspectives. The sample is purposive, comprised of practicing teachers who are engaged with mentoring trainees in Initial Teacher Education. The findings will represent a snapshot of subjective values of practicing teachers, as part of a discourse on signature pedagogies in design and technology education.
\end{abstract}

Keywords Demonstration · Teacher modelling · Explaining · Pedagogy · Teaching methods $\cdot \mathrm{Q}$ methodology $\cdot$ Design and technology

\section{Introduction}

The primary aim of this study is to analyse the subjective beliefs of teachers regarding the demonstration as a signature pedagogy in design and technology. A secondary, long-term, aim is to encourage dialogue in the design and technology community on effective pedagogies and contribute to the development of theoretical frameworks which inform classroom practice. The research question is: What do teachers of design and technology believe to be effective pedagogy when demonstrating skills and knowledge?

Matt McLain

m.n.mclain@ljmu.ac.uk

1 Liverpool John Moores University, IM Marsh Campus, Barkhill Road, Liverpool L17 6BD, UK 
Viewed from a pragmatic perspective, in formal learning "involving the use of the body and the handling of material", the act of demonstration is an essential teaching method in practical disciplines (Petrina 2007; Dewey 1916, p. 178). This paper explores teacher of design and technology views about the demonstration. Despite the subject being formally recognised in the National Curriculum for England in the late 1990s (DfE 1995, 2013; QCA 2004, 2007; DfEE 1999; NCC 1990), almost three decades on, there is limited research and pedagogical literature to underpin practice in this area (McLain et al. 2015). Whilst this study focuses on the views of teachers in England, and the relative historical and cultural context, the nature of the discussion in this paper is relevant to creative, practical and technical subjects internationally; be they craft or technology based, emerging into or embedded as a design and technology based curriculum.

The demonstration is an important pedagogical method in other practical subjects, including science (Milne and Otieno 2007) and physical education (Mosston and Ashworth 2002). In design and technology, it builds on the traditions of apprenticeship and craft education of "demonstration, observation and constant practice" (Mason and Houghton in Sayers et al. 2002, p. 44). Petrina comments on the significance of demonstrations as "the single most effective method for technology teachers" (Petrina 2007, p. 1).

\section{Central concepts and literature review}

There is relatively limited range of literature on demonstration and teacher modelling in design and technology (McLain et al. 2013). This section will draw on explicit references both within and beyond the subject, and make links with wider learning theories.

By way of definition, this paper assumes that a demonstration is, primarily, a combination of teacher modelling (DfES 2004a) and explanation (DfES 2004b)—respectively, largely visual and auditory approaches-supported other pedagogical skills such as questioning (DfES 2004c); each of which do not define demonstration, in themselves, but together are pedagogical techniques employed by the teacher of design and technology when demonstrating. Demonstration focuses on knowledge transfer of technical processes and the practical application of knowledge-demonstrated by the teacher and replicated by the learner. The teacher, as an expert subject practitioner, or more knowledgeable other (Vygotsky 1978), makes conceptual and procedural knowledge (McCormick 1997) explicit in a meaningful context. Therefore, effective modelling and explanation facilitates the development of understanding of a process, including sequence, related knowledge and next steps.

"Modelling is an active process, not merely the provision of an example. It involves the teacher as the 'expert', demonstrating how to do something and making explicit the thinking involved." (DfES 2004a: 3; emphasis mine)

"The purpose of explaining a process or procedure is to help pupils understand how things happen or work. The emphasis is on sequence and connectives such as first, next, then and finally are important." (DfES 2004b: 3; emphasis mine)

Vygotsky's (1978) theory of social constructivism and the zone of proximal development (ZPD) provide a useful lens for critiquing learning and pedagogy in the context of this study. Tappan comments on the mediating role of tools (physical and linguistic) in Vygotskian theory, and their ability to "shape human mental functioning" (1997: 78). Daniels et al. (2007) further elaborate on the Vygotsky's notion of mastery and 
development of these mental functions involving the "creation of external technology" (p. 66). Vygotsky described the process of learning (internalisation) as internal reconstruction of an external activity, "incorporated into [a] system of behaviour" (1978: 56-57). The ZPD "is the distance between the actual developmental level... and the level of potential development... under adult guidance or in collaboration with more capable peers." (p. 86).

This has implications for how and when the teacher should demonstrate, as he suggest that the evaluation of mental development should be "the assistance of others, without demonstrations, and without leading questions" (p. 88). The implication being that a demonstration, whilst being a useful scaffold for learning, obfuscates the requirement to recall and apply learning. In other words, a cautionary note should be attached to the use of demonstration, considering appropriate timing and the need to consider the appropriateness of frontloaded, just-in-time or after-failure approaches. Frontloaded instruction relies on the learner's ability to translate observations from working to long-term memory (Brown et al. 2014: 46-66; Baddeley 2000), but provides a holistic demonstration of a process or skill, in its wider context. Whereas the just-in-time approach mediates this process for the learning by removing the necessity to encode complex information to long-term memory and reduces cognitive load (Martin 2016), but removes some of the necessity for the learner to think and make decision autonomously. An after-failure approach has a number of potential applications, including with the use of a discovery learning approach (Brunner 1961), which allows for exploration and trial and error, although in some contexts may have safety implications; and in a corrective context, where the teacher observes pupils' engagement with a task or process, diagnoses misconceptions or errors and intervenes as a 'more knowledgeable other'.

As noted by McLain et al. (2015), the demonstration encompasses teacher modelling and explaining, and includes the manipulation of physical tools (materials and making), to virtual tools (software, including computer-aided manufacture) and cognitive tools (design thinking and problem solving); reflecting Wartofsky's (1979) levels of artefact. In design and technology learners explore, create and evaluate (DfE 2015). The teaching of the physical, virtual and cognitive domains has similar features, as well as distinctive differences, concerning the learner, context, resources.

Petrina (2007) identifies that the primary aim of a demonstration is to "communicate and model" procedural knowledge of "how to do something" and conceptual knowledge of "how to talk about [a] task" (p. 14); and involves demystification of equipment and procedures, explanation of expected outcomes and the application of knowledge. It is commonly accepted that much of human communication is non-verbal, mediated by symbols, signs and actions (Engeström 2009; Vygotsky 1978, cited in Tappan 1997; Wertsch 1985, 1991, cited in Tappan 1997). In neuroscience, the much debated notion of mirror neurons ( $c f$ Thomas 2012) has sought to explain the ability of primates to mimic through observation and perception. Petrina goes on to state that words in themselves are inadequate to explain technological principles and processes. In fact, this is the de facto rationale for the demonstration.

McLain et al. (2015) speculated that the fundamental and tacit nature of demonstration, as a pedagogical method, is socially assimilated through the act of observing and intuition within the community of practice (Wenger in Illieris 2009; Duguid 2008; McLain 2012; Lave and Wenger 1991), and that this may go some way to account for the limited research in the area. They go on to observe that the demonstration is a "multifaceted skill" (p. 269) combining a range of pedagogical techniques. Implicit is the notion that much teacher knowledge of demonstration, as a signature pedagogy, is engaged with at a subconscious or automatic level. Kahneman (2011) describes this as System 1, the subconscious aspect of 
the mind, which responds effortlessly and draws on prior experience and encoded memories or patterns, without the need to draw on the slower, conscious, System 2. Whilst the automatic nature of System 1 thinking is relatively quick and efficient, without the engagement of System 2, learning and the development of expertise is impaired and error (or biases) can affect practice.

In order to overcome the inherent weakness of operating solely on automatic thought and action, the practitioner adopts a reflexive interplay between the subconscious and conscious knowledge, challenging misconceptions and strengthening practice. Much has been written about the importance of reflective practice for professional development ( $c f$ Wood et al. 2009; Race 2007; McCormack 1997; Schön 1991; Luft 1982) and specifically for teachers ( $c f$ Banks et al. 2004; Jay and Johnson 2002; Brookfield 1995). Ericsson and Pool (2016) write about naïve, purposeful and deliberate practice. Purposeful practice differs from naïve practice in that it requires that the learner focus their full attention on the skill, immediate feedback and moving beyond the bounds of current knowledge or skill. Naïve practice, where the same set of skills is repeated over time with limited reflection and development, can result in more recently trained professionals performing better than seemingly more experience colleagues. Deliberate practice is described as taking purposeful practice further, enhanced by proven techniques developed by experts, with a mentor figure playing an important role, providing real-time feedback, alongside the selfreflection (internal feedback) of the practitioner. Therefore, the lack of research and documented proven techniques, in relation to teacher modelling, potentially inhibits the professional development of teachers of design and technology, and thus learners in the subject.

Visual processing, and interpretation, is sophisticated with the mind constructing and reconstructing what we see into something that we can understand. Individuals perceive and understand in different ways from differing perspectives (physical and cognitive), so the effective demonstrator should consider the important aspects of the activity that the observers need to see. Learning is a complex process, drawing on memory and sensual experience. Whilst focusing on specific 'learning styles' can be counterproductive (Sharp et al. 2008), lacking in research and mythologised (Kirschner 2017), the inclusion of variety of approaches that take into consideration the wider intelligences of learners (Brown et al. 2014; Sternberg 2011; Gardner 1983, 1993, 1995, 1999). Barlex and Carré add a situated and cultural dimension suggesting that learners "do not see things as they are, we see them as we are" (1985, p. 4). In other words, the learning experiences, be they assimilated or accommodated into memory, influence our perceptions.

When planning for learning, teachers make pedagogical choices which can be considered to be on an expansive-restrictive continuum (Fuller and Unwin 2003). In other words, the teacher, as a more knowledgeable other adapts content knowledge to be demonstrated to the learner, taking into consideration factors such as age, prior learning, expected learning outcomes. For example, when teaching a new concept or skill to a group of younger learners, the choice might be to adopt a more restrictive and teacher led approach, with questions being used to gauge recall and understanding. This restrictive approach will limit the range (and potentially the creativity) of outcomes, whereas a more expansive approach (where learner potentially make more choices) can result in a broader range of outcome, which might be less skilfully realised if the requisite skills have not already been developed. 


\section{Theoretical framework and research design}

This Q Methodology (Brown 1980) study adopted pragmatism as the philosophical and conceptual framework, in the traditions of Dewey, Pierce and James (Watts and Stenner 2012, pp. 24-46). The research paradigm is ontologically relativist, recognising the subjective nature of realities for individuals, which are multiple (Guba 1981, p. 77, 1990, pp. 17-27). As a Q Methodology study, the focus is on the socially and culturally constructed, subjective beliefs and values of the participants in relation to the object of teaching and learning practice (Watts and Stenner 2012, p. 29). In this aspect the intentions of the Q Method are interpretive and qualitative, using Peirce's "abduction", where observation of facts are used "in pursuit of an explanation and new insight" (p. 39).

Q Methodology originates from psychology research and "focuses on subjective or first person viewpoints" (Watts and Stenner 2012, p. 4). As such it does not purport to generate or confirm generalizable concepts and principles. With its roots in pragmatism, it draws on inductive and abductive reasoning with the support of mathematical modelling (factor analysis) to explore qualitative data through quantitative methods. In Q Methodology the comparison focuses on the similarities and differences between the participants, rather than their responses as is common within tradition factor analysis. A series of statements, or Q Set, that represents the broad range of opinion or belief (concourse) potentially held by the population that the sample is being drawn from. The participants then undertake a Q Sort activity. This is typically a two stage process involving a pre-sort into three categories (essential, desirable and optional, in this study), followed by the main sort where the Q Set statements are sorted into a forced-choice frequency distribution (Fig. 1) ranging from most agree to most disagree (note: the statements in this study were not designed to generate disagreement, so the 'most disagree' is relative).

The initial Q-Set was developed through a focus group of six teachers of design and technology, working with initial teacher education trainees in the North West of England, and refined by McLain et al. (2015) within an online, predominantly UK-based, community of practice for design and technology teacher educators. The list was divided into 10 categories to aid the presentation and interpretation of the 62 statements (see "Appendix").

An online Q-Sort was completed by a sample of seven teachers (Table 1) from a range of backgrounds and design and technology specialist areas, with only Participant 1 having been part of the initial focus group (above). Five of the participants are currently involved with initial teacher training (ITT) with management responsibilities that involve working both within and outside of their place of employment; Participant 4 and 7 being recently qualified teachers.

The Q-Sort for this study was conducted using an online questionnaire tool, QSortWare (Pruneddu 2014), to enable wider participation across institutions. The population for the

Most disagree

Most agree

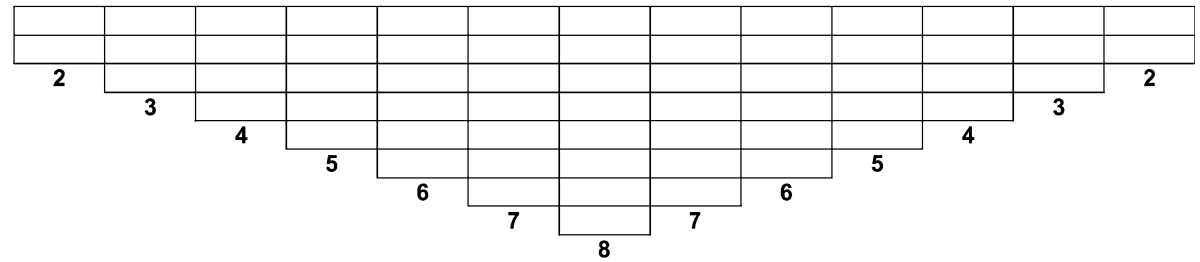

Fig. 1 Q Sort distribution 
Table 1 Factor loadings, with $X$ indicating defining sort $(\mathrm{n}=7)$

\begin{tabular}{lllll}
\hline Q-Sorts & Specialist area & Gender & \multicolumn{2}{l}{ Loadings } \\
\hline Participant 1 & Electronic and control & Male & 0.65 & X \\
Participant 2 & Graphic design & Female & 0.58 & X \\
Participant 3 & Product design & Male & 0.40 & X \\
Participant 4 & Product design & Male & 0.38 & X \\
Participant 5 & Engineering & Male & 0.03 & \\
Participant 6 & Fashion and textiles & Female & 0.16 & \\
Participant 7 & Graphic design & Mail & 0.64 & X \\
Eigenvalues & & & 1.51 & \\
Variance & & & $21 \%$ & \\
\hline
\end{tabular}

study was experienced teachers of design and technology engaged with the mentoring of ITE trainees and with links to members of the institutions that the research team represent; with the sample being purposive (Guba 1981). The factor analysis for data analysis was conducted using the PQMethod (Schmolck 2014) software.

\section{Ethics, reliability and validity}

This study was conducted with the informed consent of the participants and anonymity has been maintained for the individuals and their institutions. Limited personal information was gathered from participants. The problematic issues of researcher bias, validity and reliability (Lincoln et al. 2011) are addressed by adopting Guba's (1981) criteria for assessing trustworthiness. Guba describes the problems with imposing a scientific approach to testing the quality of naturalistic, or qualitative, research: proposing criteria of credibility, transferability, dependability and conformability (pp. 79-88). Credibility has been addressed through researcher-stakeholder engagement throughout the process of the development of the Q-Set with teachers, teacher educators and educational researchers; and presenting preliminary findings at conferences with peers in the field (McLain 2016; McLain et al. 2015). Transferability is sought by the researcher's aim to understand subjective views and avoid making generalised claims without reference to external and corroborative evidence. Dependability and confirmability of the findings will, ultimately, be tested through future studies, with larger samples using a variety of overlapping methods, and in this study are contextualised in the conceptual framework developed through the literature review.

\section{Findings and interpretation}

As an exploratory study into subjective beliefs and values, a small sample size does not pose a problem in Q Methodology, according to Watts and Stenner (2012). The findings are not being used to infer generalizable theoretical principles, rather to explore existing practice with the view to refine the 62 statements (see "Appendix") relating to teacher modelling and explaining within the subject. A future study with a larger sample would then be appropriate and more valid as a means to establish a recognised orthodoxy, with regard to demonstrations in design and technology. Further study is also required to develop and refine the Q-Set statements. 
The initial comparison of participants' responses to the Q-Sort (Fig. 2), from the PQMethod Q methodology analysis software (Schmolck 2014), indicate the superficial correlations between the participants ranging from 44 (Participants 1 and 2) to -1 (Participants 1 and 5), with Participant 5 showing the lowest correlation to the overall. This reinforces the perception that the nature of teaching and learning is complex, with no 'one size fits all' approach. The responses of both Participant 5 and 6 demonstrated weaker correlations with the other participants in the sample. Due to the sample size, inferences in relation to the participants' specialism or gender have not been drawn.

PQMethod was used to extract factors (Table 1) and reduce the data, with the Eigenvalues $(\mathrm{EV})$, or Kaiser-Guttmann criterion, above 1.00 used to indicate the statistical strength (Watts and Stenner 2012). Watts and Stenner advise that Q Methodology researcher try to extract one factor for every 6-8 participants (p. 107). Initially, two factors (groups of participants with similar responses) were extracted, but only the EV for Factor 1 (1.51) indicating potential explanatory power (i.e. $>1.00$ ) and the presence of a single common factor in the study-i.e. Factor 2 was discounted as insignificant.

The factors are the rankings of items (Q Set statements) in comparison to the participants, with the items being treated as the sample rather than the participants. These factors are the building blocks of the participants' responses to the Q sort activity, when their responses are compared. Whilst the EV for both factors indicate potential explanatory power, the factor loadings above 0.33 for each participant (Table 1) indicate a significant loading in the responses for all except Participants 5 and 6 (Factor 2). A factor loading of 0.33 is considered to be a cut-off point in Q Methodology to indicate participant's inclusion in a factor (Watts and Stenner 2012). However the relatively low loading for Participants 3 and 4 may indicate a degree of divergence between them and the other 'members' of the factor.

The factor array for the Factor 1 Q-Sort (see "Appendix") provide a useful ranking of the statements, enabling common themes to be identified. They are presented with the 62 items (statements) in the Q Set ranked from +6 to -6 , in a similar distribution to the 'forced-choice frequency distribution' described above (Fig. 1). However, it is important to note that the items that are ranked at the minus end of the spectrum do not necessarily represent disagreement, but rather that the participants arrange the items in a continuum from most agree $(+6)$ to most disagree $(-6)$, indicating the degree to which each were viewed as essential or desirable (respectively).

\section{Discussion: competent management of the learning experience}

As highlighted above, this is a single factor Q Methodology study due to the small sample size. The factor as an eigenvalue of 1.51 and explains $21 \%$ of the study variance. Five of the seven participants are significantly associated with the factor. In the original sample, there were five male participants, four of whom are associated with the factor, and two

Fig. 2 Correlation matrix between Q Sorts $(\mathrm{n}=7)$

\begin{tabular}{|c|c|c|c|c|c|c|c|}
\hline & 1 & 2 & 3 & 4 & 5 & 6 & 7 \\
\hline 1 & 100 & 44 & 25 & 20 & -3 & 16 & 16 \\
\hline 2 & & 100 & 21 & 17 & -1 & 11 & 42 \\
\hline 3 & & & 100 & 17 & 0 & 12 & 24 \\
\hline 4 & & & & 100 & 6 & 8 & 28 \\
\hline 5 & & & & & 100 & -2 & 9 \\
\hline 6 & & & & & & 100 & -3 \\
\hline 7 & & & & & & & 100 \\
\hline
\end{tabular}


female participants, one of whom is associated with the factor. Two of the Factor 1 participants identify themselves as product design specialists, two as graphic design and one as electronics and control. Of the participants in the discounted Factor 2, one identified herself as textiles and fashion and the other as engineering.

Where a specific statement from the Q-Set is referred to, in the discussion below, the bracket items indicate (a) the number of the statement and (b) the relative ranking of the statement between the five teachers in 'Factor 1' (i.e. the degree to which the group agreed or disagreed with the statement). For example, $(37:+6)$ indicated statement 37 "The teacher is competent to use equipment safely", which the group ranked strongly as most agree. The common features of the beliefs and values of the teachers in Factor 1 related, primarily, to the competency and clarity of the demonstrator. The findings are discussed below.

\section{Competence and clarity}

The highest rated statements relate to competency $(37:+6)$ and clarity $(1:+6)$ in relation to subject knowledge (see "Appendix"). Similarly the next layer of statements relate to the clarity of communication in relation to health and safety information $(38:+5)$, learning outcomes $(5:+5)$, explanations of processes and procedures $(11:+5)$ and identification of the main teaching points or steps $(17:+5)$.

Other key messages emerging in the 9 highest ranked items (Table 2), relate to classroom management and expectations of learning, and are somewhat teacher-centric as might be expected when the participant were prompted to reflect on their practice. The classroom management items are preparation for the demonstration area $(32:+4)$ and the teacher monitoring or scanning the class to ensure that learners are safe $(47:+4)$. Ranked outside the top ten (at 12) was scanning the class to monitor progress $(53:+3)$, although this diagnostic approach would require some further exploration to define how the participants measure progress during and following a demonstration. The participants' expectations related to high standards in designing and making $(39:+4)$ and explanation of how learners will make progress $(59:+3)$.

Outside of the highest ranked items, two interesting features emerge, the first relating to the consolidation of learning, within the mid-range of statements (ranked between +2 and

Table 2 Highest ranked items (ranked +4 , or above)

The teacher gives an overview of the content of the skills or knowledge being demonstrated $(\mathbf{1}: \mathbf{+ 6})$

The teacher is competent to use equipment safely $(37:+6)$

The teacher presents the learning outcomes (i.e. what learners will do or be able to do as a result) $(\mathbf{5}: \mathbf{+ 5})$

The teacher gives clear verbal explanations of processes and procedures $(\mathbf{1 1 :}+\mathbf{5})$

Appropriate information about risk is readily available to learners $(\mathbf{3 8 :}+\mathbf{5})$

The teacher identifies the main points/steps for the learners $(\mathbf{1 7}: \mathbf{+ 4})$

The teacher prepares the demonstration station/area in advance (e.g. before the lesson) (32: +4)

The teacher sets high standards and expectations for the learners in designing and making activities (39: +4)

The teacher scans and monitors the group to ensure that learners are safe $(47:+4)$

Statement number and factor array ranking in bold 
-2 ), and the second relating to learners' choices and independent learning, in the lowerrange $(-3$ to -6$)$.

\section{Consolidation of learning}

In the mid-range statements two themes emerge relating to the consolidation of learning and to the teacher's role in probing learners' understanding concepts and processes (27: 1) to recall $(26:-2)$ and apply knowledge from both within $(26:-2)$ and outside of the immediate learning experience of the current unit being taught $(23:+2)$, other design and technology units $(24:-1)$ and from other subjects $(25:-2)$. In addition, the teacher's role in using questioning to ascertain what learners understand (58: 0) and addressing their misconceptions as they arise (21: 1); both of which require a secure level of subject knowledge from the teacher in addition to pedagogical skills. The second theme relates to learners' emerging independence facilitated by the teacher allowing them to attempt a task, following a demonstration, before intervening (54:0) and the use of peer learning to demonstrate skills/knowledge to each other $(43:-1)$ and provide support before seeking the teacher's assistance $(55:-1)$. This requires a degree of self-discipline from the teacher to defer intervention and to invest time to develop a collaborative learning environment.

\section{Learners' choices and independent learning}

Statements relating to the consolidation of learning continue to emerge in the lower-range statements, with focus on: the teacher identifying $(40:-6)$ or learners being enabled by the teacher $(41:-3)$ to make choices or take alternative actions; learners speculating with prompts through teacher questioning (28: -3$)$; or thinking-out-loud to consolidate learning $(50:-5)$. The ranking of these items in the lower-range does not necessarily indicate a lack of importance or value placed on the independent learning, although this may be the case and would suggest the need for further study; it could also be the result of the necessarily restrictive nature of the demonstration of skills and knowledge requiring learners to follow defined and predetermined processes. An increasing focus on the learner's independence is reflected in the various psychomotor domains for taxonomies of learning objectives, such as Simpson (1972) or Dave (1967), developed following the development of the cognitive domain by Bloom et al. (1956) and the affective by Andersen and Krathwohl (2001). As the principle investigator, Simpson drew from expertise in practical subjects (Industrial Arts, Agriculture, Home Economics, Music, Physical Education and Art), identifying adaption and origination as the highest levels (Table 3). It also reinforces the notion that

Table 3 Simpson's psychomotor domain

\begin{tabular}{ll}
\hline Level & Description \\
\hline Perception & Observation and general perception \\
Set (or mindset) & Cognitive readiness for action \\
Guided Response & Imitation and mimicry when practicing actions \\
Mechanism & Emerging competence/proficiency, leading to independence \\
Complex Overt Response & Independence, automatic and accurate performance \\
Adaptation & Mastery and the ability to transfer skill/knowledge to other settings \\
Origination & The ability to create new approaches to activity \\
\hline
\end{tabular}


the demonstration was viewed by the teachers as an essentially restrictive, as opposed to expansive, teaching method (Fuller and Unwin 2003).

Traditionally these levels of competence have been considered to belong to the craftsman through a lengthy apprenticeship (Sennett 2009, 2008). So it is not surprising to see the role of the demonstration as a signature pedagogy in design and technology, within a subject-based national curriculum espousing a "balanced and broadly based" (DFE 2013, p. 5) learning experience. The ranking of items relating to the role of the teacher to make learners aware of choices, encourage them to speculate on the next steps or 'think-outloud' to consolidate knowledge, indicates that these pedagogical strategies may be less commonly employed and/or desirable. The learning at the adaption and origination end of the psychomotor domain is predominately expansive, as opposed to restrictive, suggesting that demonstration through teacher modelling and explanation may be less appropriate; and learner-led approaches such as microteaching, which is an effective learning method (Hattie 2009), may be more appropriate.

\section{Planning, preparation and resources}

Three statements in the Q-Set related directly to planning (8-10) and six to the use of resources (29-34). The participants in the factor group expressed a preference for staged demonstrations $(8:+2)$, breaking down complex processes, over modelling the whole process in one demonstration (9: -6 ). The low rating of the latter does not imply disagreement, but hints at a bias towards the just-in-time over the frontloaded approach. It also implies some form of rehearsal, whether cognitive for experiences teachers or realtime for novices. Preparation of the demonstration are $(32:+4)$ featured in the highest ranked statements (Table 2). Another trend identified in the lower-range statements, relates to the use learning and human resources to support demonstrations. These include the use of resources, such as instruction sheets, slideshows and videos (33: -3$)$, images, photographs and diagrams (29: -4$)$, ICT to simulate or model a process $(20:-5)$, and the use of support staff during or after the demonstration to support learners (34: -4). This was a somewhat unexpected outcome, and would suggest the need for further research to investigate this relatively low ranking of potentially useful approaches to support verbal explanations with visual reinforcement, through dual coding (Clarke and Paivio 1991).

\section{Conclusion}

As previously stated, the act of demonstrating is complex and nuanced, drawing on both generic and subject-specific pedagogical teaching methods (in particular teacher modelling and explanation). Whilst this study does not seek to propose theoretical framework or typology, it develops on the discussion begun by McLain et al. (2015). The responses in this small-scale study support the belief that competence in relation to design and technology subject knowledge is fundamental to effective teacher modelling, supported by skilful pedagogical knowledge to manage the classroom; with the sophisticated skills to consolidate learning and facilitate independence being employed as appropriate to the age and ability of the learners (Fig. 3). DfE (2013) presents the content of design and technology for 14 to 16 year olds in two categories: technical principles and designing and making principles. Whether it be in relation to the properties of material or specific making techniques, the designed artefact (be it referred to as product, system or prototype) is a 
Fig. 3 Visual representation of participants' responses

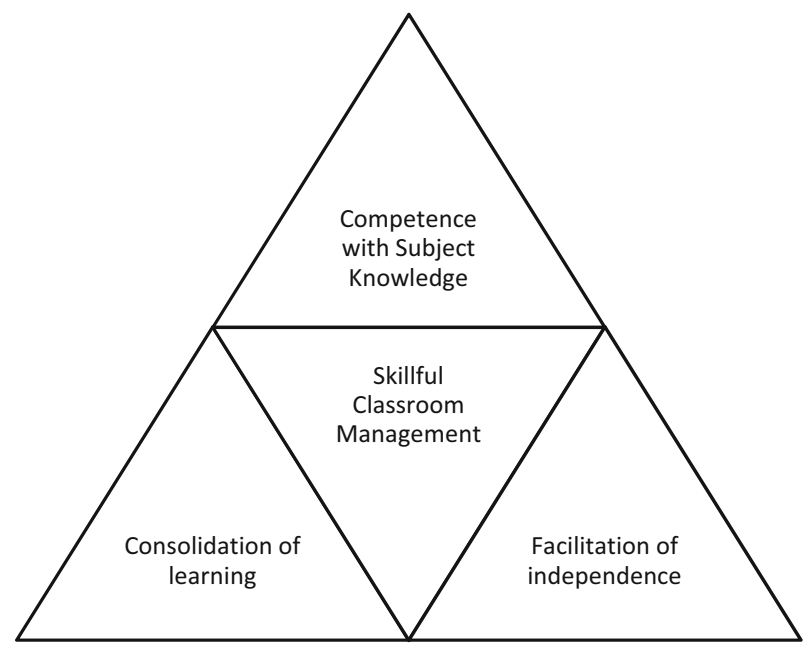

fundamental aspect of design and technology activity. Whilst there are basic concepts that can be described, such as the fact that most materials can be shaped using "wastage, addition, deforming and reforming" (p. 6), different materials have distinct means (e.g. tools and techniques) for achieving these ends. Therefore, this paper argues that the demonstration is a fundamental, or signature, pedagogy in design and technology education to support knowledge transfer; albeit within a relatively restrictive pedagogical paradigm, and other aspects of design and technology knowledge would benefit from more expansive approaches, embodied in discovery learning activities central to design and technology such as designing and making.

As a Q Methodology study, the analysis of the findings indicates the common ground between the participants in response to the 62 predefined statements on teacher modelling and explanation in design and technology. This paper explores, in more depth, the findings from the initial and exploratory small-scale study by McLain et al. (2015), which present subject knowledge and classroom management at the heart of teachers' beliefs and values. Further research is needed to explore the emerging patterns of beliefs about teacher modelling and explaining in design and technology, and McLain (2016) reports on a subsequent study involving teacher educators, using the same set of statements, which will be explored in depth with a second paper. Initial finding from McLain (2016) suggest potential avenues to develop and refine of a more concise set of statements. This study nine of the highest ranked items (Table 2), which could be used to inform discussion, debate and observation of learning in initial teacher education and for training school-based mentors.

Acknowledgements The author acknowledges David Barlex (independent consultant, UK), Dawne Bell (Edge Hill University, UK) and Alison Hardy (Nottingham Trent University, UK) as co-authors of the original paper, which this paper develops upon, presented at the Pupils Attitudes Towards Technology (PATT) conference in Marseille, in April 2015. The 62 statements used in this study were developed through dialogue initial teacher education networks of school-based mentors linked to Liverpool John Moores University and teacher educators in a UK-based design and technology Google Group.

Open Access This article is distributed under the terms of the Creative Commons Attribution 4.0 International License (http://creativecommons.org/licenses/by/4.0/), which permits unrestricted use, distribution, and reproduction in any medium, provided you give appropriate credit to the original author(s) and the source, provide a link to the Creative Commons license, and indicate if changes were made. 


\section{Appendix}

Q-Set: 62 items (statements) relating to teacher modelling, explaining and questioning in design and technology, with factor array (ranking):

\begin{tabular}{|c|c|c|c|}
\hline No. & Item & Category & Array \\
\hline 1 & $\begin{array}{l}\text { The teacher gives an overview of the content of the skills or knowledge being } \\
\text { demonstrated }\end{array}$ & Content & 6 \\
\hline 2 & The teacher uses technical language/terminology and key words & Content & 3 \\
\hline 3 & The teacher presents their expectations & Content & 3 \\
\hline 4 & The teacher presents the learning objectives (knowledge/skills) & Content & 3 \\
\hline 5 & $\begin{array}{l}\text { The teacher presents the learning outcomes (i.e. what learners will do or be } \\
\text { able to do as a result) }\end{array}$ & Content & 5 \\
\hline 6 & $\begin{array}{l}\text { The teacher refers to the application, of what is being demonstrated outside } \\
\text { the classroom context }\end{array}$ & Content & 1 \\
\hline 7 & $\begin{array}{l}\text { The teacher demonstrates skills and knowledge that learners will apply within } \\
\text { the lesson }\end{array}$ & Content & 1 \\
\hline 8 & $\begin{array}{l}\text { The teacher uses staged demonstrations, breaking down more complex } \\
\text { process into separate (linked) demonstrations }\end{array}$ & Planning & 2 \\
\hline 9 & The teacher models/explains the whole process in one demonstration & Planning & -6 \\
\hline 10 & $\begin{array}{l}\text { The teacher adapts their approach and style of demonstration to the learners, } \\
\text { dependent on age, ability, prior experience, etc. }\end{array}$ & Planning & 1 \\
\hline 11 & The teacher gives clear verbal explanations of processes and procedures & Explanation & 5 \\
\hline 12 & The teacher provides a running commentary through the demonstration & Explanation & 0 \\
\hline 13 & The teacher gives clear models/examples processes and procedures & Explanation & 2 \\
\hline 14 & $\begin{array}{l}\text { The teacher makes reference to relationships with other related concepts (e.g. } \\
\text { mathematical, scientific, technological, etc.) }\end{array}$ & Explanation & -1 \\
\hline 15 & The teacher make reference to cause and effect of decisions and/or actions & Explanation & -2 \\
\hline 16 & $\begin{array}{l}\text { The teacher uses examples, analogies and/or similes to explain processes and } \\
\text { procedures }\end{array}$ & Explanation & -2 \\
\hline 17 & The teacher identifies the main points/steps for the learners & Explanation & 4 \\
\hline 18 & $\begin{array}{l}\text { The teacher 'signposts' or indicates the next steps (i.e. "later in the lesson..." } \\
\text { or "in next lesson...") }\end{array}$ & Explanation & 0 \\
\hline 19 & $\begin{array}{l}\text { The teacher models diagnostic processes, such as using testing equipment to } \\
\text { fault-find or the application of scientific knowledge from an observation }\end{array}$ & Explanation & -2 \\
\hline 20 & The teacher uses ICT to simulate or model process or products & Explanation & -5 \\
\hline 21 & The teacher addresses learners misconceptions as they arise & Explanation & 0 \\
\hline 22 & $\begin{array}{l}\text { As part of the planned demonstration, the teacher addresses common } \\
\text { misconceptions around technical terms, concepts, etc. }\end{array}$ & Explanation & -1 \\
\hline 23 & $\begin{array}{l}\text { The teacher uses questioning to probe learners' prior knowledge from within } \\
\text { the unit/project }\end{array}$ & Questioning & 2 \\
\hline 24 & $\begin{array}{l}\text { The teacher questioning to probe learners' prior knowledge from previous } \\
\text { D\&T units/projects }\end{array}$ & Questioning & -1 \\
\hline 25 & $\begin{array}{l}\text { The teacher questioning to probe learners' prior knowledge from other } \\
\text { subjects }\end{array}$ & Questioning & -2 \\
\hline 26 & $\begin{array}{l}\text { The teacher uses questioning to enable learners to recall aspects of the } \\
\text { process demonstrated }\end{array}$ & Questioning & -2 \\
\hline 27 & $\begin{array}{l}\text { The teacher uses questioning to probe understanding of concepts, process and } \\
\text { procedures }\end{array}$ & Questioning & 1 \\
\hline
\end{tabular}




\begin{tabular}{llll}
\hline No. & Item & Category & Array \\
\hline 28 & The teacher uses questioning to encourage learners to speculate (e.g. & Questioning & -3
\end{tabular}
predicting the next step in a process)

29 The teacher uses visual resources, such as images, photographs and diagrams, Resources -4 to enhance their demonstrations

30 The teacher prepares and uses examples of the products/outcomes being Resources demonstrated

31 The teacher prepares examples showing the steps/stages of the process being Resources -1 demonstrated

32 The teacher prepares the demonstration station/area in advance (e.g. before the lesson)

33 The teacher uses resources, such as instruction sheets, slideshows or videos,
after the demonstration to support learners

34 The teacher uses other support staff (i.e. technician or teaching assistant) during, and after, the demonstration to support learners

35 The teacher identifies hazards and risks for the learners

36 The teacher prompts learners to identify hazards and risks for themselves

37 The teacher is competent to use equipment safely

38 Appropriate information about risk is readily available to learners

Resources $\quad 4$

Resources -3

Resources $\quad-4$

Health and 1

Safety

Health and 2

Safety

Health and 6

Safety

Health and 5

Safety

39 The teacher sets high standards and expectations for the learners in designing

Challenge

Challenge $\quad-6$

40 The teacher identifies alternative actions or choices learners can or need to do (e.g. design, make, evaluate)

41 The teacher enables learners to identify alternative actions or choices that they can make (e.g. design, make, evaluate, etc.)

42 The teacher plans and uses extension or enrichment activities for able learners

43 The teacher encourages/supports learners to demonstrate skills and knowledge to their peers

44 The teacher encourages learners to participate in fault finding and quality control

45 The teacher ensures that they make eye contact with members of the whole group

46 The teacher scans and monitors the group, as they are teaching, to ensure that the learners are engaged

47 The teacher scans and monitors the group to ensure that learners are safe

Challenge $\quad-3$

Challenge $\quad-4$

Challenge $\quad-1$

Challenge $\quad-2$

Engagement $\quad 0$

Engagement 2

Engagement 4

Engagement -1

Engagement -3

49 The teacher can modify their tone when talking to/with different sized groups and in different situations

50 The teacher encourages learners to 'think-out-loud' to consolidate knowledge and understanding

51 The teacher explains the function and/or context of the matter (i.e. knowledge and/or skill) being demonstrated

52 The teacher encourages learners to reflect on values (e.g. the impact of a technology on society, the environment, etc.)

53 The teacher scans the room after the demonstration to monitor learners' progress

Engagement $\quad-5$

Engagement $\quad-5$

Engagement -3

Learning $\quad 3$

54 The teacher waits for learners to attempt a task before intervening $\quad$ Learning $\quad 0$ 


\begin{tabular}{|c|c|c|c|}
\hline No. & Item & Category & Array \\
\hline 55 & $\begin{array}{l}\text { The teacher encourages learners to support each other before seeking the } \\
\text { assistance of the teacher }\end{array}$ & Learning & -1 \\
\hline 56 & $\begin{array}{l}\text { After the demonstration, the teacher moves around the room to support } \\
\text { learners }\end{array}$ & Learning & 1 \\
\hline 57 & $\begin{array}{l}\text { The teacher shows/explains the process/skill to individuals who have } \\
\text { misunderstood processes or concepts shortly after a demonstration }\end{array}$ & Learning & -4 \\
\hline 58 & $\begin{array}{l}\text { The teacher uses questioning to ascertain what a learner understands, when } \\
\text { they have not fully understood the demonstration }\end{array}$ & Assessment & 0 \\
\hline 59 & The teacher explains what learners are expected to do to make progress & Assessment & 3 \\
\hline 60 & The teacher makes his/her expectations of the learners' outcomes clear & Assessment & 2 \\
\hline 61 & $\begin{array}{l}\text { The teacher provides examples of outcomes of a process that exemplify the } \\
\text { skills being modelled }\end{array}$ & Assessment & 0 \\
\hline 62 & $\begin{array}{l}\text { The teacher ensures that all learners know what they need to do to make } \\
\text { progress }\end{array}$ & Assessment & 1 \\
\hline
\end{tabular}

\section{References}

Andersen, L. W., \& Krathwohl, D. R. (Eds.). (2001). A taxonomy for learning, teaching, and assessing: A revision of Bloom's taxonomy of educational objectives. London: Pearson.

Baddeley, A. (2000). The episodic buffer: a new component of working memory? Trends in Cognitive Sciences, 4(1), 417-423. doi: 10.1016/S1364-6613(00)01538-2. Accessed 1 Aug 2017.

Banks, F., Barlex, D., Jarvinen, E.-M., O’Sullivan, G., Owen-Jackson, G., \& Rutland, M. (2004). DEPTHdeveloping professional thinking for technology teachers: An international study. International Journal of Technology and Design Education, 14, 141-157.

Barlex, D., \& Carré, C. (1985). Visual communication in science. Cambridge: Cambridge University Press.

Bloom, B. S., et al. (1956). Taxonomy of educational objectives: The classification of educational goals: Handbook 1, cognitive domain. New York: Longman Higher Education.

Brookfield, S. (1995). Becoming a critically reflective teacher. San Francisco: Jossey-Bass Inc., a Willey Company.

Brown, S. R. (1980). Political subjectivity: Applications of $Q$ methodology in political science. New Haven, CT: Yale University Press.

Brown, P. C., Roediger, H. L., III, \& McDaniel, M. A. (2014). Make it stick: The science of successful learning (1st ed.). London: The Belknap Press of Harvard University Press.

Bruner, J. S. (1961). The act of discovery. Harvard educational review.

Clark, J. M., \& Paivio, A. (1991). Dual coding theory and education, Educational Psychology Review, 3(3), 149-210. doi: 10.1007/BF01320076. Accessed 18 Jan 2017.

Daniels, H., Cole, M., \& Wertsch, J. V. (2007). The cambridge companion to Vygotsky. Cambridge: Cambridge University Press.

Dave, R. (1967). Psychomotor domain. In Berlin: International conference of educational testing.

Dewey, J. (1916). Democracy and education: An introduction to the philosophy of education. New York: The Macmillan Company.

DfE. (1995). Design and Technology in the national curriculum. London: Department for Education.

DfE. (1999). Design and technology—the national curriculum for England. London: Department for Education and Employment and Qualifications and Curriculum Authority.

DfE. (2013). National curriculum in England: Framework document [online]. Available at: https://www. gov.uk/government/collections/national-curriculum. Accessed 18 Jan 2017.

DfE. (2015). Design and technology: GCSE subject content [online]. Available at: https://www.gov.uk/ government/publications/gcse-design-and-technology. Accessed 18 Jan 2017.

DfES. (2004a). Pedagogy and practice: Teaching and learning in secondary schools unit 6: Modelling [online]. Available at http://webarchive.nationalarchives.gov.uk/20110809101133/http://nsonline.org. uk/node/97131. Accessed 18 Jan 2017. 
DfES. (2004b). Pedagogy and practice: Teaching and learning in secondary schools unit 8: Explaining [online]. Available at http://webarchive.nationalarchives.gov.uk/20110809101133/http://nsonline.org. uk/node/97131. Accessed 18 Jan 2017.

DfES. (2004c). Pedagogy and practice: Teaching and learning in secondary schools unit 7: Questioning [online]. Available at http://webarchive.nationalarchives.gov.uk/20110809101133/http://nsonline.org. uk/node/97131. Accessed 18 Jan 2017.

Duguid, P. (2008). The art of knowing: Social and tacit dimensions of knowledge and the limits of the community of practice. In A. Amin \& J. Roberts (Eds.), Community, economic creativity, and organisation. Oxford: Oxford University Press.

Engeström, Y. (2009). Expansive learning: Towards an activity-theoretical reconceptualisation. In K. Illeris (Ed.), Contemporary theories of learning: Learning theorists... in their own words. Oxon: Routledge.

Ericsson, A., \& Pool, R. (2016). Peak: Secrets from the new science of expertise. New York: Houghton Mifflin Harcourt.

Fuller, A., \& Unwin, L. (2003). Learning as apprentices in the contemporary UK workplace: Creating and managing expansive and restrictive learning environments. Journal of Education and Work, 16(4), 406-427.

Gardner, H. (1983). Frames of mind: The theory of multiple intelligences. New York: Basic Books.

Gardner, H. (1993). Multiple intelligences: The theory in practice. New York: Basic Books.

Gardner, H. (1995). The unschooled mind: How children think and how schools should teach. New York: Basic Books.

Gardner, H. (1999). Intelligences reframed: Multiple intelligences for the 21st century. New York: Basic Books.

Guba, E.G. (1981). Criteria for assessing the trustworthiness of naturalistic inquiries. Educational Communication and Technology, 29(2), 75-91. Available at: http://www.jstor.org/stable/30219811. Accessed 18 Jan 2017.

Guba, E. G. (1990). The alternative paradigm dialogue. In E. G. Guba (Ed.), The paradigm dialogue. London: Sage.

Hattie, J. (2009). Visible learning: A synthesis of over 800 meta-analyses relating to achievement. Oxon: Routledge.

Jay, J. K., \& Johnson, K. L. (2002). Capturing complexity: a typology of reflective practice for teacher education. Teaching and Teacher Education, 18, 73-85. doi: 10.1016/S0742-051X(01)00051-8. Accessed 18 Jan 2017.

Kahneman, D. (2011). Thinking, fast and slow. London: Penguin Group.

Kirschner, P. (2017). Stop propagating the learning styles myth. Computers \& Education, 106, 166-171.

Lave, J., \& Wenger, E. (1991). Situated learning: Legitimate peripheral participation. Cambridge: Cambridge University Press.

Lincoln, Y. S., Lynham, S. A., \& Guba, E. G. (2011). Paradigmatic controversies, contradictions and emerging confluences, revisited. In N. K. Denzin \& Y. S. Lincoln (Eds.), The SAGE handbook of qualitative research (4th ed.). London: SAGE Publications Ltd.

Luft, J. (1982). The Johari Window: A graphic model of awareness in interpersonal relations. In L. C. Porter \& B. Mohr (Eds.), Reading book for human relations training. Arlington: NTL Institute for Applied Behavioral Science.

Martin, A. J. (2016). Using Load Reduction Instruction (LRI) to boost motivation and engagement. Leicester: British Psychological Society.

Mason, R., \& Houghton, N. (2002). The educational value of making. In S. Sayers, J. Morley, \& B. Barnes (Eds.), Issues in design and technology teaching. London: RoutledgeFalmer.

McCormack, R. (1997). Conceptual and procedural knowledge. International Journal of Technology and Design Education, 7, 141-159.

McLain, M. (2012). An (auto)ethnographic narrative of the teaching of designing within design and technology in the English curriculum. Procedia Social and Behavioral Sciences, 45, 318-330. Available at: http://www.sciencedirect.com/science/journal/18770428/45. Accessed 11 Apr 2013.

McLain, M. (2016). Teacher educator perspectives on pedagogical modelling and explaining in design and technology: A Q methodology study. In PATT32 conference, technology education for 21 st century skills, 23-26 August 2016, Delft University of Technology and HU University of Applied Sciences.

McLain, M., Barlex, D., Bell, D., \& Hardy, A. (2015). Teacher perspectives on pedagogical modelling and explaining in design and technology: A Q methodology study. In PATT 29 conference, plurality and complementarity of approaches in design \& technology education, 6-10 April 2015, Marseille Université. 
McLain, M., Bell. D., \& Pratt, A. (2013). Show-how know-how (Part 1): Theory and practice for demonstrating in design and technology. D\&T Practice, 3/2013. Wellesbourne, UK: Design and Technology Association.

Milne, C., \& Otieno, T. (2007). Understanding engagement: Science demonstrations and emotional energy. Science Education, 91(4). doi: 10.1002/sce.20203. Accessed 18 Jan 2017.

Mosston, M., \& Ashworth, S. (2002). Teaching physical education (5th ed.). San Francisco: Pearson Education Inc.

NCC. (1990). Technology in the national curriculum. London: Department for Education and Science and the Welsh Office.

Petrina, S. (2007). Advanced teaching methods for the technology classroom. London: Information Science Publishing.

Pruneddu, A. (2014). QSortWare [Online software]. Available at http://www.qsortouch.com. Accessed 18 Jan 2017.

QCA. (2004). Design and Technology—the national curriculum for England. London: Department for Education and Skills and Qualifications and Curriculum Authority.

QCA. (2007). Design and Technology: Programme of study for key stage 3 and attainment target. London: Qualifications and Curriculum Authority.

Race, P. (2007). The lecturer's toolkit: A practical guide to assessment, learning and teaching (3rd ed.). Abingdon: Routledge.

Sayers, S., Morley, J., \& Barnes, B. (Eds.). (2002). Issues in design and technology teaching. London: RoutledgeFalmer.

Schmolck, P. (2014). PQPethod (Version 2.35) [Computer program]. Available at http://schmolck.userweb. mwn.de/qmethod/index.htm. Accessed 18 Jan 2017.

Schön, D. A. (1991). The reflective practitioner: How professionals think in action. Farnham: Ashgate Publishing Limited.

Sennett, R. (2008). The craftsman. London: Penguin.

Sennett, R. (2009). The Social Craftsman: Global Perspectives on the Economic Crisis [video online]. London: University College London. Available at: https://itunes.apple.com/gb/itunes-u/socialcraftsman-global-perspectives/id390418862?mt=10. Accessed 18 Jan 2017.

Sharp, J. G., Bowker, R., \& Byrne, J. (2008). VAK or VAK-uous? Towards the trivialisation of learning and the death of scholarship. Research Papers in Education, 23(3), 293-314.

Simpson, E. J. (1972). The classification of educational objectives in the psychomotor domain. Washington, DC: Gryphon House.

Sternberg, R. J. (2011). The theory of successful intelligence. In R. J. Sternberg \& S. B. Kaufman (Eds.), Cambridge handbook of intelligence. New York: Cambridge University Press.

Tappan, M.B. (1997). Language, culture, and moral development: A Vygotskian perspective. Developmental Review, 17(1), 78-100 [online]. doi: 10.1006/drev.1996.0422. Accessed 18 Jan 2017.

Thomas, B. (2012). What's So special about mirror neurons? [online article]. Available at https://blogs. scientificamerican.com/guest-blog/whats-so-special-about-mirror-neurons/. Accessed 18 Jan 2017.

Vygotsky, L. S. (1978). Mind in society. Cambridge: Harvard University Press.

Wartofsky, M. W. (1979). Models: representation and the scientific understanding. Dordrecht: D. Reidel Publishing Company.

Watts, S., \& Stenner, P. (2012). Doing Q methodological research: Theory, method and interpretation. London: Sage Publications Ltd.

Wenger, E. (2009). A social theory of learning. In K. Illeris (Ed.), Contemporary theories of learning: Learning theorists in their own words. London: Routledge.

Wertsch, J. (1985). Vygotsky and the social formation of mind. Cambridge, MA: Harvard University Press.

Wertsch, J. (1991). Voices of the mind: A sociocultural approach to mediated action. Cambridge, MA: Harvard University Press.

Wood, N., Rust, C., \& Horne, G. (2009). A tacit understanding: The designer's role in capturing and passing on the skilled knowledge of master craftsmen. International Journal of Design, 3(3), 65-78. 